\title{
PERSIAPAN SPIRITUAL SEBAGAI UPAYA MENGHADAPI PERSALINAN YANG NYAMAN DI WILAYAH KERJA PUSKESMAS PAMITRAN KOTA CIREBON 2018
}

\author{
Endang Nurrochmi ${ }^{1 *}$, Neli Nurlina ${ }^{1}$, Rinela Padmawati ${ }^{1}$ \\ ${ }^{1}$ Prodi Kebidanan Cirebon, Poltekkes Kemenkes Tasikmalaya, Indonesia \\ *Email : endangnurrochmi72@gmail.com
}

\begin{abstract}
The process of labor seems to be a medical event, so that women without sufficient understanding tend to give up their bodies to those who are considered to know more. Prayers or positive affirmations are indeed believed to be able to dispel negative energies, free fear, and create harmony in the form of thoughts and feelings positive ones. It will also help babies born in a calm and comfortable atmosphere. The method used in this activity is to provide material to the final trimester pregnant women about. Physical and mental preparation through affirmation and prayer (especially for followers of Islam) give for 3 times at PONED Pamitran. Then pregnant women are given guidebooks to read and practice prayer and affirmations. Then it is evaluated after the mother gives birth by interview to reveal experiences during the delivery process. The results are an increase in the level of knowledge about pregnancy, childbirth, preparation for childbirth and spiritual preparation in facing labor, the distress scale of pregnant women is at a mild stress level and decreases after hypnobirthing relaxation and prayer and affirmation for the smooth delivery process. The conclusion is that preparation for facing childbirth should not only be physical but mental and spiritual readiness is very important to be prepared to face the labor process that cannot be predicted by the process. All health facilities can add maternal class material with spiritual preparation and childbirth assistants in an effort to obtain a pleasant and minimal trauma experience.
\end{abstract}

Keywords: spiritual preparation, labor

\section{ABSTRAK}

Proses persalinan seolah-olah menjadi peristiwa medis, sehingga para perempuan tanpa pemahaman yang cukup cenderung menyerahkan tubuhnya pada pihak yang dianggap lebih tahu Doa atau afirmasi positif memang sangat dipercaya dapat menghalau energi-energi negatif, membebaskan rasa takut, serta menciptakan harmoni berupa pikiran dan perasaan yang positif. Juga akan membantu bayi lahir dalam suasana yang tenang dan nyaman. Metode yang dilakukan pada kegiatan ini adalah memberikan materi kepada ibu hamil trimester akhir tentang persiapan fisik dan mental melalui afirmasi dan doa (khusus untuk penganut agama Islam) berikan selama 3 kali di PONED Pamitran. Kemudian ibu hamil diberikan buku panduan untuk dibaca dan berlatih doa dan afirmasi. Kemudian dievaluasi setelah ibu melahirkan dengan wawancara untuk mengungkapakan pengalaman selama proses persalinan. Hasil terdapat peningkatan tingkat pengetahuan tentang kehamilan, persalinan, persiapan menghadapi persalinan dan persiapan spiritual menghadapi persalinan, skala distress ibu hamil berada pada tingkat stress ringan dan mengalami penurunan setelah diberikan relaksasi hypnobirthing dan melakukan doa dan afirmasi untuk kelancaran proses persalinan. Kesimpulan persiapan menghadapi persalin sebaiknya tidak hanya fisik saja tetapi kesiapan mental dan spiritual sangat penting untuk dipersiapkan untuk menghadapi proses persalinan yang tidak dapat diprediksi prosesnya. Semua fasilitas kesehatan dapat menambah materi kelas ibu dengan persiapan spiritual dan pendamping persalinan sebagai upaya memperoleh pengalaman melahirkan yang menyenangkan dan minim trauma.

Kata Kunci : persiapan spiritual, persalinan, 


\section{PENDAHULUAN}

Kehamilan dan persalinan adalah reaksi berantai yang tak bisa dipisahkan dalam kehidupan wanita normal. Saat kita mempersiapkan secara menyeluruh (body, mind and spirit), proses kehamilan dan persalinan dapat berlangsung dengan aman, lancar dan nyaman. Terlebih lagi bila provider dan klien memiliki kesadaran untuk menggunakan konsep persalinan alami dan memperhatikan semua aspek tubuh manusia secara holistic, penuh dengan kelembutan (gentle birth).

Pergeseran paradigma tanpa disadari telah menyebabkan terjadinya proses reduksi dimana manusia menjadi robot yang tidak lagi terdiri dari satu kesatuan body, mind and spirit. Proses persalinan pun kemudian berubah seolah-olah menjadi peristiwa medis, sehingga para perempuan tanpa pemahaman yang cukup cenderung menyerahkan tubuhnya pada pihak yang dianggap lebih tahu.

Berangkat dari fenomena tersebut, lahirlah kesadaran kembali pada konsep persalinan yang alami dengan memperhatikan semua aspek tubuh manusia secara holistic. Konsep persalinan ini disebut dengan gentle birth. Sebuah konsep persalinan yang tenang dan santun dengan memanfaatkan semua unsure yang alami. Tenang karena ibu dalam kondisi rileks dan tidak terburu-buru serta santun karena ibu diminimalkan rasa sakitnya. Metode ini mengajarkan perempuan untuk menyatu, mempercayai isyarat tubuh, serta meyakini bahwa tubuh mampu berfungsi sebagaimana mestinya sehingga komplikasi bisa dihindari dan ditekan serendah mungkin.

Spiritualitas adalah suatu keyakinan dalam hubungannya dengan yang Maha Kuasa, Maha Pencipta (Hamid, 1999). Keyakinan spiritual akan berupaya mempertahankan keharmonisan, keselarasan dengan dunia luar. Berjuang untuk mendapatkan kekuatan ketika sedang menghadapi penyakit fisik, stress emosional, keterasingan sosial bahkan ketakutan menghadapi ancaman kematian. Semua ini merupakan kekuatan yang timbul di luar kekuatan manusia. Keyakinan spiritual sangat penting bagi petugas kesehatan karena dapat mempengaruhi tingkat kesehatan dan perilaku klien

Doa atau afirmasi positif memang sangat dipercaya dapat menghalau energy-energi negative, membebaskan rasa takut, serta menciptakan harmoni berupa pikiran dan perasaan yang positif. Juga akan membantu bayi lahir dalam suasana yang tenang dan nyaman. Dengan keyakinan bahwa siapapun wanita bisa menjalankan kehamilan dan persalinan normal dengan alami, nyaman jika telah mempersiapkan diri sejak awal kehamilan, bahkan jauh sebelum konsepsi. Oleh karena itu, kesadaran akan pra-penciptaan ini harus dimulai dari berhubungan intim yang sadar dan sakral, menjalani kehamilan yang sehat, bahagia, persalinan yang ramah, hingga pengasuhan anak yang penuh kesadaran. Semuanya perlu dilakukan sejak janin baru menghuni rahim calon bayi, bahkan sebelum konsepsi.

\section{METODE}

Untuk mempersiapkan fisik dan mental ibu hamil banyak yang dapat dilakukan diantaranya mengikuti kelas ibu hamil, banyak membaca buku atau artikel tentang kehamilan dan persalinan. Dalam kegiatan ini materi yang akan diberikan kepada ibu hamil meliputi persiapan fisik dan mental melalui afirmasi dan doa (khusus untuk penganut agama Islam) :

1. Membuat persiapan materi panduan afirmasi dan doa

2. Menentukan materi tentang kehamilan dan persalinan

3. Persiapan menghadapi persalinan

4. Melakukan latihan relaksasi

5. Melakukan latihan relaksasi dan afirmasi

6. Melakukan relaksasi dan menghapal doa kehamilan dan menjelang persalinan Rencana kegiatan dengan membagi 3 kali pertemuan untuk masing-masing ibu hamil. Dengan kegiatan setiap pertemuan sebagai berikut:

Tabel 1. Persiapan Spiritual Ibu Hamil

\begin{tabular}{cllll} 
Pertemuan & Kegiatan & \multicolumn{1}{c}{ Materi } & Target/sasaran & Waktu \\
\hline 1 & $\begin{array}{l}\text { Diskusi dan } \\
\text { meteri }\end{array}$ & $\begin{array}{l}\text { Proses kehamilan , persalinan } \\
\text { dan persiapan menyusui }\end{array}$ & Ibu hamil & 1 Kali \\
$2-3$ & $\begin{array}{l}\text { Diskusi dan } \\
\text { meteri }\end{array}$ & $\begin{array}{l}\text { Relaksasi, afirmasi dan doa } \\
\text { Ibu hamil }\end{array}$ & 2 Kali \\
\hline
\end{tabular}


Setelah proses pemberian materi dan latihan selanjutnya dievaluasi pada saat persalinan. Ibu diminta untuk menceritakan penerapan afirmasi dan proses persalinan sesuai dengan afirmasi dan doa yang ibu panjatkan.

\section{HASIL DAN PEMBAHASAN}

Gambaran karakteristik reponden adalah rata-rata usia responden 20-25 tahun, paritas 1-3 orang dan pekerjaan ibu rumah tangga. Rata-rata nilai pre tes 47,5 dan post test 65 dan rata-rata skala distress 11-12, yang artinya ibu-ibu relative tenang dan perlu konsultasi untuk meningkatkan kesiapan menghadapi persalinan. Hasil pre tes dan pos tes adalah terdapat peningkatan tingkat pengetahuan ibu tentang kehamilan dan persalinan. Dengan menyadari kehamilan dengan sadar sejak konsepsi sampai 40 minggu kehamilan diharapkan ibu dapat melewati semua prosesnya dengan nyaman dan bahagia, masalah yang dialami dapat diatasi dengan baik dan tidak menimbulkan masalah yang berkepanjangan tak terselesaikan. Penting untuk tahu dan paham pula tentang proses persalinan dimulai dengan mengetahui tanda persalinan, tahap persalinan, apa yang harus dilakukan pada setiap tahap persalinan, tindakan untuk memberikan kenyamanan baik yang dilakukan ibu maupun pendamping persalinan, sehingga mendapatkan pengalaman positif bebas trauma dari persalinan tersebut.

Pada pengetahuan ini harus disadari bahwa pengetahuan memegang peranan yang sangat penting bagi calon orang tua, karena dalam proses kehamilan dan persalinan. Rasa takut menghadapi proses ini muncul ketika pasangan merasa tidak tahu apa-apa atau tidak tahu apa yang harus dipersiapkan, tidak tahu apa yang terjadi dalam tubuh dan tidak tahu prosesnya. Tidak tahu apa apa yang akan dilakukan kepada dirinya apabila terjadi sesuatu yang tidak diharapkan terjadi. Karena ketidaktahuan itu seringkali calon orang tua memasrahkan segalanya kepada petugas kesehatan.

Bila pengetahuan yang dimiliki ibu rendah atau kurang maka dia tidak tahu apa yang akan membuat ibu panic bila tanda-tanda persalinan muncul dan tidak tahu apa harus dilakukan, ketika proses dimulai dengan kontraksi yang semakin inten bila tidak tahu cara mengatasikan akan membuat ibu frustrasi dan menyerah pada petugas kesehatan dan tidak jarang tindakan medis yang diambil menimbulkan trauma untuk ibu. Bila ibu pada persalinan sebelumnya mengalami trauma maka pada persalinan selanjutkan akan muncul trauma baru bila trauma sebelumnya tidak diatasi sampai tuntas. Berbeda bila ibu memiliki tingkat pengetahuan tinggi dan mau memberdayakan diri untuk melakukan persiapan persalinan dengan baik semua kepanikan dan trauma kemungkinan besar tidak dialami oleh ibu.

Hasil penilaian skala distress semua ibu hamil berada pada stress ringan. Hal ini menunjukkan bahwa semua ibu tidak mengalami masalah fisik dan psikologis yang merupakan salah tanda bahwa ibu hamil siap menghadapi persalinannya. Tingkat stress atau kecemasan sedang diakhir kehamilan merupakan sesuatu yang wajar dan bila mendapat penanganan yang baik diharapkan tidak meningkat menjadi stress berat. Upaya yang dilakukan adalah dengan berlatih relaksasi melalui hypnobirthing. Pada akhir sesi setiap harinya dilakukan relaksasi dan hasil evaluasi mereka menyatakan nyaman dan segar ketika proses relaksasi berakhir. Dan diharapkan ibu hamil dapat melakukan relaksasi secara mandiri di rumah.

Proses persalinan tidak akan terlupakan, terekam dalam pikiran dengan jelas, istilah "you are what you think" adalah apaun yang dipikirkan akan terwujud dalam perilaku bahkan kesehatan tubuh kita. Hypnobirthing merupakan salah satu metode healing trauma. Rasa sakit sebenarnya diakibatkan rasa rakut dan kecemasan akan fase-fase persalinan dan biasanya kita berupaya untuk menghindarinya. Rasa cemas dan takut menyebabkan rasa nyeri dan membuat kontraksi rahim semakin keras. Kecemasan dan ketakutan memacu keluarnya adrenalin sehingga serviks kaku dan membuat proses persalinan melambat. Kecemasan dan ketakutan menyebabkan pernapasan tidak teratur dan mengurangi asupan sirkulasi oksigen bagi tubuh dan bayi. Tetapi karena sudah tertanam di diri kita bahwa melahirkan itu menyakitkan sehingga banyak yang berpikir bahwa proses persalinan harus nyeri dan persalinan yang nyaman itu hal yang tidak mungkin.

Rencana persalinan adalah tempat persalinan di PONED Pamitran, ditolong bidan yang ramah dan suasana kekeluargaan, didampingi suami yang aktif melakukan pijat, membelai lembut rambut dan diiriingi music rileksasi .Dengan harapan anak lahir sehat, menjadi anak soleh dan solehah serta jenis kelamin sesuai dengan harapan. Yang paling pertama utama dan terpenting adalah persalinan harus aman bagi ibu, janin dan penolong. Hal tersebut menunjukkan bahwa semua ibu sudah berencana melahirkan di sarana pelayanan kesehatan dan juga menunjukan kesadaran untuk berupaya 
mendapatkan proses persalinan yang aman dan nyaman, dan apabila terjadi komplikasi dapat tertangani segera.

Perencanaan persalinan harus dibuat oleh calon orang tua dengan mempertimbangkan bahwa persalinan merupakan pengalaman yang tak terlupakan dan dikenang sepanjang hidup, sehingga alangkah indah bila pengalaman tersebut adalah pengalaman menyenangkan jauh dari trauma

Terdapat lima orang ibu hamil yang telah bersalin dan setelah dilakukan wawancara mereka mengungkapkan mereka lebih tenang menghadapi persalinan, walau prosesnya lama (terlama 2 hari sejak merasakan mulas sampai lahir) tetapi mereka dapat melalui dengan tenang bila dibandingkan dengan persalinan yang lalu. Suami dapat mendampingi persalinan. Dari hasil wawancara kepada ibu dan suami di dapatkan bahwa persalinan kali ini isterinya lebih pasrah walau suami sendiri tetap mengalami kepanikan ketika kontraksi muncul.

Ketika kontraksi muncul isteri banyak bernapas melakukan doa dan berdzikir mengucap Asmaul husna sebagai bukti kepasrahan kepada yang Maha Kuasa. Beberapa suami melakukan pijatan ringan di bokong, mengusap lembut kepala ibu dan ikut berempati merasakan nikmatnya kontraksi yang dirasakan isterinya. Salah satu cara paling efektif bagi seorang wanita untuk mengurangi rasa sakit saat proses persalinan adalah bernapas dan focus. Pernapasan terjadi secara otomatis, persalinan akan terasa sangat melelahkan sehingga kita memiliki kendali atas pernapasan dapat sangat bermanfaat terutama membuat ibu merasa rilek. Ketika kita bernapas, memberitahu untuk berkonsentrasi dan memperlambat pernapasan.

\section{SIMPULAN}

Hasil pre tes dan pos tes adalah terdapat peningkatan tingkat pengetahuan ibu tentang kehamilan dan persalinan. Hasil penilaian skala distress semua ibu hamil berada pada stress ringan. Rencana persalinan adalah tempat persalinan di PONED Pamitran Ibu hamil yang telah bersalin dan mengungkapkan mereka lebih tenang menghadapi persalinan, walau prosesnya lama (terlama 2 hari sejak merasakan mulas sampai lahir) tetapi mereka dapat melalui dengan tenang bila dibandingkan dengan persalinan yang lalu. Persiapan menghadapi persalin sebaiknya tidak hanya fisik saja tetapi kesiapan mental dan spiritual sangat penting untuk dipersiapkan untuk menghadapi proses persalinan yang tidak dapat diprediksi prosesnya. Semua fasilitas kesehatan dapat menambah materi kelas ibu dengan persiapan spiritual dan pendamping persalinan sebagai upaya memperoleh pengalaman melahirkan yang menyenangkan dan minim trauma.

\section{DAFTAR PUSTAKA}

1. Kemenkes RI. Riset Kesehatan Dasar 2013. Jakarta : Departemen Kesehatan Republik Indonesia

2. Aprilia Y, 2014, Gentle Birth Balance, Penerbit CV Andi Offsett, Yogyakarta.

3. , 2010, Hipnostetri, Rileks Nyaman dan Aman Saat Hamil dan Melahirkan, GagasMedia, Jakarta.

4. Davis E, Bonaro, 2010, Orgasmic Birth, Your Guide To A Safe, Satisfying, And Pleasureable Birth Experience, Rodale, NY 10017.

5. Mongan MF, 2005, Hypnobirting, The Mongan Methode, Metode melahirkan secara aman, mudah dan nyaman.

6. Simkin P, 2013, The Birth Partner, A Complete Duide to Childbirth for Dads, Doulas And Other Labor Companions, Fourth Edition, Massachusetts, Harvard Common Press.

7. Henderson \& Jones,2001, Buku Ajar: Konsep Kebidanan, EGC, Mosby.

8. Kuswandi L, 2013, Hypnobirthing, A Gentle Way to Give Birth, Pustaka Bunda

9. Manuaba, I.B.G, et all, 2010, Ilmu Kebidanan, Penyakit Kandungan dan KB, Edisi II. EGC, Jakarta.

118 Edukasi Masyarakat Sehat Sejahtera (EMaSS) : Jurnal Pengabdian kepada Masyarakat Volume 1 No. 2 Tahun 2019 
10. Tornetta G, 2008, Painless Chilbirth, An Empowering Journey Through Pregnancy and Birth, Cumberland House.

11. Wiknjosastro, 1999, Ilmu Kebidanan, Edisi Ke-3 cetakan ke-5, Jakarta, YBPSP.

12. Yazid, 2016, Doa dan Wirid, Cetakan ke-32, Pustakan Imam Asy-Syafii 